\title{
Study Abroad Programs: Making Safety A Priority
}

\author{
Michael Craig Budden, Southeastern Louisiana University, USA \\ Connie B. Budden, Southeastern Louisiana University, USA \\ Rusty Juban, Southeastern Louisiana University, USA \\ Aristides Baraya, Southeastern Louisiana University, USA
}

\begin{abstract}
Increasingly, students are participating in study abroad programs. Such programs provide participants a variety of learning experiences. Developing cross-cultural appreciation, communication skills, maturity and a less ethno-centric mindset are among the impacts study abroad programs offer. However, care must be taken to assure student safety and health while on such trips. One program's efforts to assure the safety and wellness of participants while abroad are presented.
\end{abstract}

Keywords: Study Abroad; Student Safety; Insurance

\section{INTRODUCTION}

t appears that universities are increasing the number of opportunities available to their students to pursue study-abroad programs. As globalization's impact continues to encroach on more and more fields of study, students are increasingly seeking study abroad programs that not only earn them credit for participation, but also provide learning experiences and insights incapable of being taught in a traditional classroom.

According to one report, over 260,000 US students earned credit for study abroad efforts in 2008-2009 (www.IIE.org/en/Who-We-Are/News-and-Events/Press-Center/Press-Releases/2010/2010-11-15-Open-Doors-USStudy-Abroad). And, while the number of students seeking study abroad opportunities declined slightly in 20082009 over the previous year, many universities in the past decade have experienced an increase in the numbers of students seeking study abroad. For example, at the University of South Carolina - Columbia Campus, 251 students participated in study abroad in 2002, while a decade later, more than 1,100 were participating (www.studyabroad.SC.edu).

Altbach (2002) pointed out a decade ago, internationalization of business curricula had ceased to be an option and had become a necessity in schools seeking to achieve a global vision for their students. Baraya, Budden, and Juban (2005) emphasized that understanding global strategies and having multi-cultural encounters was essential to a quality education. As for learning, Juban, Baraya, and Budden (2006) proffer that adult learners will learn better when they are actively involved in the search for knowledge.

Besides a better understanding of multicultural issues and globalization, study abroad programs can develop networking opportunities and cross-cultural communication skills (Budden, Baraya, \& Juban, 2005). Budden and Budden (2011) emphasize that the teaching of ethics in a global environment can add much to a student's experience and knowledge. Indeed, even in programs that do not require a foreign language, the practice of placing and in essence isolating students in a foreign environment may do much to improve those students' communication skills.

While the majority of persons pursuing study abroad opportunities offered by universities in the US are US citizens, study abroad programs have also found favor with international students who desire to see and experience cultures foreign to them. These programs can be life-changing experiences. As Budden and Budden (2006) found, foreign students can learn much about US students by being with them in a foreign environment. 
Once the benefits of study abroad are known, the issue becomes one of implementation. Should a school join one of the many existing "turn key" programs that are offered by organizations and companies touting such, or should a school have its own, stand-alone program. As Juban, Baraya, and Budden (2006) point out, a stand-alone program has much merit but does require effort.

Whether a program is part of a larger commercial or multi-school effort or a stand-alone program, safety of participants should be a priority. Indeed, as Walkenhorst, Tennis, and McClellan (2011) emphasize, parents expect their children will be safe in school-sponsored programs. Despite concern, Begun (2001) reports on a study in the 1998-1999 school year in which over 1,200 American students studied in 19 countries that were on the US State Department's warning list. With high profile cases like the Natalie Holloway case, civil uprisings, earthquakes, tsunamis, and sexual assaults, many are taking notice of potential perils facing participants in study abroad programs. Indeed, some colleges are hiring security firms to assess risks associated with study abroad programs (Vander Werf, 2007).

Southeastern Louisiana University's College of Business has been conducting study abroad programs for 15 years. The College's first and longest running program involves a trip to Costa Rica. The program takes place in late May each spring. The three professors managing the program have developed a list of safety recommendations and criteria that they share with their students at a mandatory meeting prior to the trip. Students are warned that even though Costa Rica is a relatively safe country, students need to be aware of their surroundings, travel with friends, avoid strangers, and use common sense when abroad.

The list of safety recommendations and criteria they share with students is provided here.

\section{CRITERIA AND SAFETY RECOMMENDATIONS FOR STUDY ABROAD}

Everyone who plans to participate should realize that:

1. You must have a passport. You will need to bring it with you (but not in your suitcase).

2. The International Initiatives Office on campus requires a photocopy of your passport on file before you will be approved to participate in the program.

3. We advise you to get a tetanus shot before going. Or, check with your doctor to make sure yours is up to date. The Parish Health Unit can provide the shot inexpensively and quickly.

4. $\quad$ Bring a small first aid kit (supplies, bandages, antiseptic cream, etc).

5. Bring rain ponchos (cheap throwaway types).

6. $\quad$ Bring suitcases on wheels.

7. Bring comfortable tennis/running shoes.

8. Except for fresh fruit, don't eat anything that is not cooked.

9. Use phone cards that can be purchased locally.

10. If you don't fly with the group days/times, you must secure your own transportation. Everyone should provide a copy of their individual travel itinerary to your faculty coordinator.

11. NO ILLEGAL DRUGS - AT ALL! Don't even think about it. Needed prescription medicines should be brought in their labeled bottle. You represent Southeastern while in Costa Rica - act like it. You must obey school rules - and the law - always.

12. Absences from lectures, inappropriate behavior, etc will result in severe grade penalty and potentially, other penalties.

13. Don't walk alone - watch your pockets, purses, etc. Pickpockets and pick-purses are common.

14. If you leave the hotel, please be sure to let others know where you are going and when you expect to return. Don't leave alone. Always travel in groups.

15. Use only "RED CABS" or use Hotel provided transportation (van) only.

16. Bring adequate spending money (alums recommend \$500-\$800). NEVER FLASH MONEY! Traveler's checks don't spend. No $\$ 100$ s or $\$ 50$ s - the hotel may cash big bills, but stores will not take big bills.

17. Remember, you will need money to go on excursions (canopy tour, rafting etc) if you desire to do so.

18. Don't carry large amounts of cash. You should take $\$ 20-\$ 30$ when you go out.

19. When you arrive, you will be given an itinerary. Follow it. Be on the bus on time. 
20. Bring a camera - preferably an inexpensive one.

21. Use the safe in the hotel (Don't lose keys); make sure the safe/safety deposit box is locked before leaving.

22. Please no non-school guests/strangers should be let into your rooms.

23. Only bring one or two credit cards, driver's license, and passport.

24. Don't bring iPods or cell phones. If you do, know they are highly desirable to pickpockets and thieves.

25. Never wear shorts in the city or to lectures. Business attire to lectures/visits only.

26. You should be aware that sex with minors in Costa Rica is a federal offense punishable by lengthy prison sentences.

27. Don't gamble. Again, don't flash money.

28. Don't bring expensive jewelry.

29. Bring a photocopy of your passport (or the trip-issued ID) when traveling on excursions in the country. Leave the original in the safe.

30. If you are injured or become ill, notify (or have someone notify) your faculty members as quickly as possible.

\section{Women}

31. Don't wear shorts in the city. Never wear shorts to a lecture.

32. Purses should be closed and secured with a zipper (and a flap, if possible).

33. Wear comfortable, neat clothing (suits are not necessary).

\section{Men}

34. Avoid prostitutes and areas where they congregate.

35. Wear comfortable clothes (nice jeans are okay, slacks and knit shirts are better - No t-shirts on lectures; bring at least two nice shirts.

36. Keep wallets in pockets with buttons. Don't carry a large amount of cash - ever.

\section{TRIP ORIENTATIONS AND FOLLOW-UP}

Our faculty members hold three pre-trip meetings where we emphasize these recommendations and others and relate the experiences of past trips. After each trip, a short survey is administered to participants to gather their thoughts on the tours/speakers, the excursions, hotels, transportation, and guides. This has allowed us to fine-tune the program and improve participant safety and satisfaction.

For instance, over the years, we have eliminated some tours/speakers while continuing to rely on others. Also, as for bringing cash, there has been a noticeable drop in the amount recommended by participants over the past decade, as stores, restaurants, and excursion providers in Costa Rica increasingly accept credit cards.

Our students have always enjoyed air-conditioned hotels - a fact of note when our students meet other schools' students whose accommodations do not include air-conditioning. Indeed, we also try to book hotels with restaurants and which are closely situated to safe shopping and entertainment areas. Again, over the years we have changed hotels as local conditions and student sentiments have changed.

The inability to use US-based cell phones in Costa Rica until recently was a sore point for many. Until Costa Rica agreed to CAFTA (it was the last signatory), the use of US phones was prohibited. Now, most phones will work in Costa Rica, though we warn our students to check with their individual carriers to ascertain charges related to the use of their phones prior to the trip.

\section{CONCLUSION}

Our students are notified they are to be on good behavior as they are on a school-sponsored trip. Proper and safe behavior and personal decorum are expected at all times. The participation fee pays not just for tuition, room, board, and local travel, it also provides a limited accident and health insurance policy - just in case. The 
medical care in Costa Rica is excellent, and over the years the faculty have developed relationships with healthcare providers that have benefited the program's participants. Like parents, we want students to have a great time, experience new cultures and have new experiences, but to do so in a safe manner.

\section{AUTHOR INFORMATION}

Dr. Michael Craig Budden is the Benjamin Paul Jones Professor of Retailing at Southeastern. His research interests include commercial law, ethics, retail, and business education. E-mail: mbudden@ @selu.edu (Corresponding author)

Ms. Connie B. Budden is an instructor of Management at Southeastern. Her research interests include business education, global business, human resource management issues, and business sustainability. E-mail: cbudden@selu.edu

Dr. Rusty Juban is a Professor of Management at Southeastern. His research interests include business education, management and leadership development, and global issues in management. E-mail: rjuban@ selu.edu

Dr. Aristides Baraya is the Director of the Hispanic Business and Leadership Institute at Southeastern. His research interests include youth education, entrepreneurship, Hispanic advancement, and leadership. E-mail: abaraya@selu.edu

\section{REFERENCES}

1. Altbach (2002). Perspectives on internationalizing higher education. Center for International Higher Education, Boston College.

2. Baraya, A., Budden, M. C., \& Juban, R. L. (2005, June). Enhancing business students' international capabilities through global education programs. Journal of Business and Economics Research, 3(6), 45-50.

3. $\quad$ Begun, B. (2001, February 26). Hi, Mom. I'm in Nepal. Newsweek, 137(9), 33.

4. Budden, C. B., \& Budden, M. C. (2011, January). It is a small world after all: Teaching business ethics in a global environment. American Journal of Business Education, 4(1), 89-92.

5. Budden, M. C., Baraya, A. R., \& Juban, R. L. (2005, June). Developing a MBA study-abroad program at Southeastern Louisiana University. Business Communication Quarterly, 68(2), 233-236.

6. Budden, M. C., \& Budden, H. L. (2006, October). Assimilation conundrum: Austrian befriends Americans in Costa Rica. Journal of College Teaching and Learning, 3(10), 35-38.

7. Juban, R. L., Baraya, A. R., \& Budden, M. C. (2006, February). Going it alone: Developing an independent study abroad program. Journal of College Teaching and Learning, 3(2), 61-66.

8. Lemoine, A., Mayer, A., Gordon, A., Johnson, M., \& Budden, M. C. (2011, January). The role of higher education in personal relationships. Contemporary Issues in Education Research, 4(1), 9-13.

9. Institute of International Education Open Doors Report (2010). Retrieved from www.IIE.org/en/Who-WeAre/News-and-Events/Press-Center/Press-Releases/2010/2010-11-15-Open-Doors-US-Study-Abroad

10. University of South Carolina (2012). Retrieved from www.Studyabroad.sc.edu/index.php?option=com_content\&view=article\&id=136\&item $=633$

11. Vander Werf, M. (2007, March 3). Riskier business. The Chronicle of Higher Education, A1-A32.

12. Walkenhorst, M., Tennis, A., \& McClellan, M. (2011, September). Educated risks. Smart Business St. Louis, 4(9), 14. 